\title{
Pengaruh posisi condong kedepan dan terapi pursed lips breathing terhadap derajat sesak napas penderita Penyakit Paru Obstruktif Kronik (PPOK)
}

\author{
Usastiawaty Cik Ayu Saadiah Isnainy ${ }^{1}$, Sekardhyta Ayuning Tias² \\ 1Program Studi Diploma III Keperawatan Universitas Malahayati. Email: usastiawatycasi@gmail.com \\ ${ }^{2}$ RSUD Dr. H. Abdul Moeloek Bandar Lampung. *Email: sekara459@gmail.com
}

\author{
Abstract \\ Pursed lips breathing and an forward leaning posture to reduce dyspnea \\ in Chronic Obstructive Pulmonary Disease (COPD) patients.
}

\begin{abstract}
Background: An in-depth personal interview in December 2019 with nurses of Dr. H. Abdul Moeloek Hospital of Lampung Province where the hospital is one of the referred hospitals for COPD in Lampung Province found that the COPD patient number increased every day. In average, there were 20 COPD patients registered every day with mostly having complaint of heavy breathless and recurring out of breath seizures. In total, in 2018, there were 491 COPD patients recorded at medical record indicating the increase compared with 237 patients in the previous year.

Purpose: Knowing the effect of forward leaning posture and pursed lips breathing in respiratory rate on COPD.

Methods: A quantitative study with quasi experimental one group pretest - posttest approach. The population of the study involved 93 people. The purposive sampling of 17 respondent. The statistical analysis was through T-Dependent. Result: The mean score of the breathing condition of the COPD patients before given FLP and PLB interventions was 86.71 with deviation standard 1.649 , error standard 00.400 and min-max score $85-90$. After the FLP and PLB interventions, the mean score was 92.82 with 2.856 standard deviation, 0.693 error standard, and min-max scores 88 97. The T-dependent statistical test found $P$ value $0.000(a<0.05)$.

Conclusion: There was the effect of forward leaning posture and pursed lips breathing in respiratory rate on COPD. This research can be used as a recommendation for setting operational standard in the management of COPD patients in order to improve the caring quality of the nurses, particularly on handling FLP and PLB therapy.
\end{abstract}

\section{Keywords: Pursed Lips Breathing; Forward Leaning Posture; Dyspnea; COPD}

Pendahuluan: Hasil wawancara personal dengan perawat di RSUD Dr. H. Abdul Moeloek Provinsi Lampung, dimana rumah sakit tersebut merupakan salah satu rumah sakit rujukan wilayah Lampung, pada Desember 2018 didapatkan informasi bahwa jumlah penderita PPOK setiap harinya meningkat. Rata-rata dalam sehari terdapat 20 penderita dengan PPOK yang dirawat dengan keluhan sesak nafas yang sangat berat dan sebagian besar dari mereka adalah pasien yang datang dengan serangan sesak nafas berulang. Sedangkan berdasarkan data rekam medik sebanyak 491 pasien dengan PPOK pada tahun 2018, kejadian ini mengalami peningkatan dari tahun sebelumnya, yaitu sebanyak 237 pasien mengalami PPOK pada tahun 2017.

Tujuan: Diketahui pengaruh posisi CKD dan PLB terhadap tingkat sesak nafas pada pasien PPOK.

Metode: Jenis penelitian Kuantitatif dengan rancangan penelitian menggunakan Quasi Eksperimental dengan pendekatan one group pretest - posttest design. Populasi sebanyak 93 dan sampel yang digunakan sebanyak 17 orang, pengambilan sampel pada penelitian adalah purposive sampling. Uji statistik menggunakan uji t-dependen.

Hasil : Rata-rata posisi kondisi pernafasan pasien PPOK sebelum diberikan terapi CKD Dan PLB dengan mean 86,71 standar deviasi 1,649 standar eror 00,400 dan nilai min-max 85-90, dan setelah diberi intervensi mean 92,82 standar deviasi 2,856 standar eror 0,693 dan nilai min-max 88-97. Hasil uji statistik menggunakan $t$-dependen didapat nilai $p$ value $0.000(\alpha<0.05)$.

Simpulan : Hasil penelitian ini terdapat pengaruh posisi CKD Dan PLB Terhadap Tingkat Sesak Nafas Pada Pasien PPOK.

Saran: Dapat dijadikan standar operasional penatalaksanaan pasien dengan PPOK sebagai upaya untuk meningkatkan kualitas asuhan keperawatan dengan cara memberikan posisi CKD dan PLB.

Kata Kunci: Pursed Lips Breathing; Condong Kedepan; Sesak Nafas; PPOK 
Pengaruh posisi condong kedepan dan terapi pursed lips breathing terhadap derajat sesak napas penderita Penyakit Paru Obstruktif Kronik (PPOK)

\section{PENDAHULUAN}

PPOK merupakan penyebab utama morbiditas dan kematian diseluruh dunia. Prevalensi, morbiditas dan mortalitas terkait dengan PPOK telah meningkat dari waktu kewaktu dan lebih tinggi pada pria dibandingkan pada wanita. Lebih dari 3 juta orang meninggal karena PPOK. Salah satu penyebab PPOK adalah asap tembakau (perokok aktif). Perubahan gaya hidup karena pembangunan ekonomi mempengaruhi peningkatan penggunaan tembakau di negaranegara berpenghasilan tinggi. Kematian terkait penyebab PPOK terus meningkat (Purwanti, Hartoyo, \& Wulandari, 2016).

Penyakit Paru Obstruksi Kronis (PPOK) menyebabkan paru kronik yang ditandai dengan adanya hambatan aliran udara disaluran pernafasan yang tidak reversible. Hambatan aliran udara tersebut umumnya bersifat progresif dan berhubungan dengan respons inflamasi pulmonal terhadap partikl atau gas berbahaya. Hal ini disebabkan oleh meningkatnya usia harapan hidup dan semakin tingginya pajanan faktor risiko, seperti faktor pejamu semakin banyaknya jumlah perokok khususnya pada kelompok usia muda, serta pencemaran udara di dalam ruangan maupun di luar ruangan dan di tempat kerja (Khotimah, 2013).

Penyakit Paru Obstruktif Kronik (PPOK) merupakan salah satu dari kelompok penyakit tidak menular yang telah menjadi masalah kesehatan masyarakat di Indonesia. Hal ini disebabkan oleh meningkatnya usia harapan hidup dan semakin tingginya pajanan faktor risiko, seperti faktor pejamu yang diduga berhubungan dengan kejadian PPOK. Semakin banyaknya jumlah perokok khususnya pada kelompok usia muda, dan pencemaran udara di dalam ruangan maupun di luar ruangan serta di tempat kerja (Ariyani, Sarbini, \& Yuliati, 2013).

Penyakit paru biasanya ditandai dengan hambatan aliran udara di saluran nafas yang bersifat progresif nonreversible atau reversible parsial. Penyakit kardio respirasi didefenisikan sebagai penyakit yang ditandai oleh adanya obstruksi saluran pernapasan yang tidak reversible sepenuhnya. Sumbatan aliran udara ini umumnya bersifat progresif dan berkaitan dengan proses inflamasi abnormal paru-paru terhadap partikel atau gas yang berbahaya (Singh, Agusti, Anzueto, Barnes, Bourbeau, Celli, \& Varela, 2019). Faktor risiko Kebiasaan merokok merupakan satu satunya penyebab kausal yang terpenting, jauh lebih penting dari faktor penyebab lainnya (Perhimpunan Dokter Paru Indonesia, 2011).

Salah satu bagian integral dari manajemen COPD adalah membersihkan jalan nafas untuk mengatasi gejala klinis seperti produksi sputum dan sesak napas yang menyebabkan penurunan VEP1, produksi sputum yang berlebihan, dan terganggunya mobilisasi toraks. Perawat dapat membantu pasien PPOK untuk memulihkan kondisi fisiknya dan memperbaiki pola nafasnya dengan memutus mata rantai keluhan yang ada dengan Active Cycle of Breathing Technique (ACBT) (Huriah, \& Ningtias, 2017). Oksigen sebagai komponen gas dan unsur vital dalam proses metabolisme, untuk mempertahankan kelangsungan hidup seluruh sel tubuh. Secara normal elemen ini diperoleh dengan cara menghirup udara ruangan dalam setiap kali bernapas. Penyampaian oksigen ke jaringan tubuh (Takatelide, Kumaat, \& Malara, 2017).

Latihan fisik dengan durasi yang singkat tidak lebih dari 30 menit. Saturasi oksigen adalah presentasi hemoglobin yang berikatan dengan oksigen dalam darah (Simanjuntak, Engka, \& Marunduh, 2016). Pengobatan pada pasien sesak nafas dengan PPOK dapat dikurangi dengan diberikan obat-obatan bronkodilator, kortikosteroid, antihistamin, steroid, antibiotik, dan ekspektoran. Selain diberikan obat-obatan tersebut, latihan keperawatan mandiri bagian tubuh bawah dan atas juga disarankan berupa latihan pernafasan diafragmatik, pemberian posisi tripod, latihan batuk kencang atau batuk terkontrol olahraga aerobik terapi berhenti merokok juga disarankan untuk memperlambat progresi penyakit (Black, \& Hawks. 2014).

Modalitas fisioterapi yang dapat digunakan dalam penanganan kasus PPOK, salah satu nya yaitu dengan tehnik Pursed Lip Breathing (PLB). Pursed Lip Breathing (PLB) dapat gunakan untuk membantu bernapas lebih efektif, yang memungkinkan untuk mendapatkan oksigen yang dibutuhkan. PLB melatih untuk mengeluarkan napas lebih lambat, sehingga bernapas lebih mudah, pada tingkat yang lebih nyaman, apakah sedang beristirahat atau bergerak (Edwin, Basuki, Physio, \& Isnaini, 2013).

Usastiawaty Cik Ayu Saadiah lsnainy' Program Studi Diploma III Keperawatan Universitas Malahayati. Email: usastiawatycasi@gmail.com

Sekardhyta Ayuning Tias ${ }^{2^{*}}$ RSUD Dr. H. Abdul Moeloek Bandar Lampung. *Email: sekara459@gmail.com 
Pengaruh posisi condong kedepan dan terapi pursed lips breathing terhadap derajat sesak napas penderita Penyakit Paru Obstruktif Kronik (PPOK)

Sesak napas menjadi masalah utama pada PPOK dan sebagai alasan penderita mencari pengobatan. Sesak napas bersifat persisten serta progresif dan juga sebagai penyebab ketidakmampuan penderita untuk melakukan aktivitas. Gejala sesak napas harus dievaluasi secara rutin pada setiap penderita PPOK. Sesak napas biasanya dinilai dengan menghitung fungsi paru dengan cara spirometri, namun untuk menilai sesak napas pada penderita PPOK dapat juga digunakan kuesioner Modified Medical Research Council scale (MMRC scale) (Anwar, Chan, \& Basyar, 2012).

Sesak napas atau Dispnea dimana keadaan sulit bernapas dan merupakan gejala utama dari penyakit kardiopulmonal. Seseorang yang mengalami sesak napas sering mengeluh napasnya menjadi pendek atau merasa tercekik (Laksana, \& Berawi, 2015).

Obstruksi saluran napas perifer secara progresif menyebabkan udara terperangkap selama ekspirasi dan mengakibatkan hiperinflasi. Hiperinflasi menurunkan kapasitas inspirasi (KI) dan peningkatan kapasitas residu fungsional (KRF) selama latihan dan kelainan ini dikenal sebagai hiperinflasi dinamik (Seraswati, 2017).

Penyakit paru obstruksi kronik sering dikaitkan dengan gejala ekserbasi akut. Pasien PPOK dikatakan mengalami ekserbasi akut bila kondisi pasien mengalami perburukan yang bersifat akut dari kondisi sebelumnya yang stabil dan dengan variasi gejala harian normal sehingga penyebab ekserbasi akut ini biasanya disebabkan oleh infeksi (bakteri atau virus), bronkospasme, polusi udara atau obat golongan sedatif. Sekitar sepertiga penyebab ekserbasi akut dapat ditandai dengan gejala yang khas, seperti sesak nafas yang semakin bertambah, batuk produktif dengan perubahan volume atau purulensi sputum, atau dapat juga memberikan gejala yang tidak khas seperti malaise, fatigue, dan gangguan susah tidur (Sudoyo, Setiyohadi, Alwi, Simadibrata, \& Setiati, 2009).

PLB sebagai latihan pernapasan yang menekankan pada proses ekspirasi yang dilakukan secara tenang dan rileks dengan tujuan untuk mempermudah proses pengeluaran udara yang terjebak oleh saluran napas. Melalui teknik ini, maka udara yang ke luar akan dihambat oleh kedua bibir, yang menyebabkan tekanan dalam rongga mulut lebih positif. Tekanan posistif ini akan menjalar ke dalam saluran napas yang menyempit dan bermanfaat untuk mempertahankan saluran napas untuk tetap terbuka. Dengan terbukanya saluran napas, maka udara dapat ke luar dengan mudah melalui saluran napas yang menyempit serta dengan mudah erpengaruh pada kekuatan otot pernapasan untuk mengurangi sesak napas (Alsaggaf, Seeni, Delaney, Williams, \& Gutierrez, 2017).

Selain PLB terapi lainnya yang dapat digunakan adalah memberikan posisi condong kedepan (CKD) untuk mengurangi sesak, Posisi CKD akan meningkatkan otot diafragma dan otot interkosta eksternal pada posisi kurang lebih 45 derajat. Otot diafragma merupakan otot utama inspirasi dan otot interkosta eksternal juga merupakan otot inspirasi. Otot diafragma yang berada pada posisi 45 derajat menyebabkan gaya grafitasi bumi bekerja cukup adekuat pada otot utama inspirasi tersebut dibandingkan posisi duduk atau setengah duduk. Gaya grafitasi bumi yang bekerja pada otot diafragma memudahkan otot tersebut berkontraksi bergerak ke bawah memperbesar volume rongga toraks dengan menambah panjang vertikalnya. Begitu juga dengan otot interkosta eksternal, gaya grafitasi bumi yang bekerja pada otot tersebut mempermudah iga terangkat keluar sehingga semakin memperbesar rongga toraks dalam dimensi anteroposterior (Khasanah, \& Maryoto, 2016).

\section{METODE PENELITIAN}

Jenis penelitian kuantitatif dengan rancangan menggunakan desain Quasi Eksperimental dengan pendekatan one group pretest - posttest design. Penelitian ini sudah lulus kelaikan etik dari Komisi Etik Penelitian Kesehatan (KEPK) Universitas Malahayati dan dilaksanakan pada Juli 2019 di Ruang Melati RSUD Dr. H. Abdul Moeloek. Populasi sebanyak 93 responden yang mengalami PPOK dan sampel sebanyak 17 responden. Teknik sampling dengan purposive sampling. Cara pengumpulan data dengan menggunakan data primer yaitu pasien yang mengalami sesak nafas pada penderita PPOK menggunakan pulse oxymeter dan dimasukan kedalam lembar observasi. Setelah lembar observasi dikumpulkan, dilakukan pengolahan data. 
Pengaruh posisi condong kedepan dan terapi pursed lips breathing terhadap derajat sesak napas penderita Penyakit Paru Obstruktif Kronik (PPOK)

Melakukan pengkajian dan observasi sesak nafas pasien PPOK dengan cara mengukur SpO2 dengan menggunakan pulse oxymeter kemudian dicatat ke dalam lembar observasi pada hari pertama. Memposisikan pasien pada posisi duduk di kursi atau di tempat tidur dengan punggung membungkuk ke depan membentuk sudut 135 derajat dan kepala serta lengan disangga atau diletakan di atas meja atau lengan ditopang kepala atau lengan ditopang paha. Posisi tersebut diberikan pada pasien yang mendapatkan oksigen dan obat bronkhodilator setelah 4 jam pemberian obat tersebut dan tindakan posisi dilakukan selama 10 menit. Sedangkan yang dimaksud dengan tindakan PLB, adalah suatu tindakan breathing exercise berupa nafas atau inspirasi melalui hidung selama 2-3 detik diikuti ekspirasi secara perlahan melalui mulut minimal waktu 2 kali inspirasi (4-6 detik) dilakukan selama 30 menit dengan toleransi jeda istirahat selama 5 menit selama 3 kali(5 intervensi, jeda waktu istirahat 5 menit, dilanjutkan 5 menit ke 2 dan jeda waktu istirahat 5 menit, kemudian 5 menit ke 3 dan waktu istirahat/selesai salama 5 menit) selanjutnya dilakukan pengukuran $\mathrm{SpO} 2$ menggunakan pulse oxymeter. Melakukan pengkajian dan observasi sesak nafas pasien PPOK dengan cara mengukur SpO2 setelah diberi terapi PLB dan CKD menggunakan pulse oxymeter.

\section{HASIL}

Tabel 1. Rata-Rata Kondisi Pernafasan Pasien PPOK Sebelum dan Sesudah Diberikan Terapi N=17

\begin{tabular}{lcccc}
\hline Pernafasan Pasien & Mean & Std. Deviasi & S.Eror & Min-Max \\
\hline Pre-test & 86,71 & 1,649 & 0,400 & $85-90$ \\
Post-test & 92,82 & 2,856 & 0,693 & $88-97$ \\
\hline
\end{tabular}

Rata-rata kondisi pernafasan pasien PPOK sebelum diberikan terapi CKD Dan PLB terhadap 17 responden, dengan mean $\mathrm{SpO}^{2}$ pada responden sebesar 86,71 nilai $\mathrm{SpO}^{2}$ pada responden terendah sebesar 85 dan nilai $\mathrm{SpO}^{2}$ pada responden tertinggi sebesar 90 . Rata-rata kondisi pernafasan pasien PPOK sesudah diberikan terapi CKD Dan PLB terhadap 17 responden, dengan mean SpO2 pada responden sebesar 92,82 nilai $\mathrm{SpO}^{2}$ pada responden terendah sebesar 88 dan nilai $\mathrm{SpO}^{2}$ pada responden tertinggi sebesar 97.

Tabel 2. Pengaruh Posisi CKD Dan PLB Terhadap Tingkat Sesak Nafas N=17

\begin{tabular}{ccccc}
\hline Variabel & Mean & Std. Dev & SE & $p$-value \\
\hline Pre-test & 86,71 & 1,649 & 0,400 & 0.000 \\
Post-test & 92,82 & 2,856 & 0,693 & 0.000 \\
\hline
\end{tabular}

Rata-rata kondisi pernafasan pasien PPOK sebelum diberikan terapi CKD Dan PLB terhadap 17 responden, dengan mean $\mathrm{SpO}^{2}$ pada responden sebesar 86,71 nilai $\mathrm{SpO}^{2}$ pada responden terendah sebesar 84 dan nilai $\mathrm{SpO}^{2}$ pada responden tertinggi sebesar 90 . Dan sesudah diberikan terapi CKD Dan PLB dengan mean $\mathrm{SpO}^{2}$ pada responden sebesar 92. Hasil uji statistik menggunakan tes-dependent didapat nilai $p$-value 0.000 artinya terdapat Pengaruh Posisi CKD Dan PLB Terhadap Tingkat Sesak Nafas Pada Pasien PPOK. Pada penelitian ini terdapat peningkatan $\mathrm{SpO}^{2}$ pada responden yang mengalami PPOK, meskipun tidak mengalami peningkatan yang signifikan, terdapat 4 responden yang mengalami peningkatan $\mathrm{SpO}^{2}$ namun masih berada pada hipoksia ringan.

PEMBAHASAN
Rata-Rata Kondisi Pernafasan Pasien PPOK
Sebelum dan Sesudah Diberikan Terapi
Penelitian ini sejalan dengan teori yang
dikemukakan bahwa sesak nafas mengalami
kesulitan untuk bernafas sehingga menimbulkan
sensasi yang tidak nyaman dan tidak
menyenangkan karena membutuhkan usaha

Usastiawaty Cik Ayu Saadiah lsnainy' Program Studi Diploma 111 Keperawatan Universitas Malahayati. 
Pengaruh posisi condong kedepan dan terapi pursed lips breathing terhadap derajat sesak napas penderita Penyakit Paru Obstruktif Kronik (PPOK)

bernafas berlebihan (Kurniawati, 2012). Penyakit Paru Obstruktif Kronis (PPOK) dapat dicegah dan dapat diobati. Dengan karakteristik hambatan aliran udara menetap dan progresif yang disertai dengan peningkatan-peningkatan respon inflamasi kronis pada saluran napas dan paru terhadap partikel berbahaya (Tanto, Liwang, Hanifati, \& Pradipta, 2014).

Pendapat peneliti penyebab sesak nafas tersebut bukan hanya karena obstruksi pada bronkus atau bronkhospasme saja tapi lebih disebabkan karena adanya hiperinflasi. Oleh karena itu pada penanganan PPOK tidak hanya mengandalkan terapi farmakologi saja melainkan terapi non farmakologi juga merupakan hal penting yang harus dilakukan untuk mengurangi sesak nafas. Pada penelitian ini, saat dilakukan pengukuran hari pertama nilai rata-rata sesak nafas berada pada skor 86,71 , dan nilai min 85 , max 90, yang artinya responden berada pada ambang batas hipoksia ringan dan hipoksia sedang. Pendapat peneliti pada pasien yang mengalami PPOK terjadi gangguan otot pernapasan yang dipengaruhi kontraksi otot dan kekuatan otot pernapasan. Hilangnya daya elastis paru pada PPOK menyebabkan hiperinflasi dan obstruktif jalan napas kronik yang mengganggu proses ekspirasi sehingga volume udara yang masuk dan keluar tidak seimbang serta terdapat udara yang terjebak (air trapping).

Penelitian ini sejalan dengan teori bahwa PLB sebagai latihan pernapasan yang menekankan pada proses ekspirasi yang dilakukan secara tenang dan rileks dengan tujuan untuk mempermudah proses pengeluaran udara yang terjebak oleh saluran napas. Melalui teknik ini, maka udara yang ke luar akan dihambat oleh kedua bibir, yang menyebabkan tekanan dalam rongga mulut lebih positif. Tekanan positif ini akan menjalar ke dalam saluran napas yang menyempit dan bermanfaat untuk mempertahankan saluran napas untuk tetap terbuka. Dengan terbukanya saluran napas, maka udara dapat ke luar dengan mudah melalui saluran napas yang menyempit serta dengan mudah berpengaruh pada kekuatan otot pernapasan untuk mengurangi sesak napas (Permadi, \& Wahyudi, 2017).

Pada penelitian ini, setelah diberikan posisi PLB dan CKD nilai rata-rata sesak nafas berada pada skor 92,82 nilai min 88 max 97 yang artinya responden berada pada hipoksia ringan. Pendapat peneliti Pursed Lip Breathing (PLB) juga dapat meningkatkan volume tidal dan mengurangi gejala Air Trapping atau udara yang terjebak pada alveoli, mengurangi hiperinflasi, sehingga meningkatkan ventilasi dan perfusi, serta menurunkan tingkat kandungan $\mathrm{PaCO} 2$ dalam darah. Ukuran rongga torak yang semakin kecil membuat tekanan intra alveolus semakin meningkat. Peningkatan tekanan intra alveolus yang melebihi tekanan atmosfir menyebabkan udara mengalir keluar dari paru. Proses ventilasi yang meningkat pada pasien PPOK yang diposisikan CKD akan meningkatkan pengeluaran $\mathrm{CO} 2$ dan meningkatkan asupan oksigen ke dalam intra alveolus.

\section{Pengaruh Posisi CKD Dan PLB Terhadap Tingkat Sesak Nafas}

Penelitian ini sejalan dengan teori bahwa Pursed lips breathing (PLB) dengan penekanan pada saat ekspirasi bertujuan dalam memudahkan pengeluaran udara air trapping atau udara yang terjebak oleh saluran nafas. PLB dapat menghambat udara keluar dengan menggunakan kedua bibir sehingga menyebabkan tekanan dalam rongga mulut menjadi lebih positif. Keberhasilan PLB yaitu melakukan latihan dengan keadaan santai (Bakti, \& Dwi, 2015).

Hasil penelitian dari 17 responden, pada pengukuran pertama mengalami hipoksia ringan dan sedang, sedangkan pada pengukuran ke dua keseluruhan responden mengalami peningkatan $\mathrm{SpO}^{2}$, sebanyak 6 responden mengalami perubahan dari hipoksia menjadi normal, hal ini dapat disebabkan karena penyakit yang diderita dari responden tidak berada dalam hipoksia berat, sedangkan dari faktor usia tidak mempengaruhi peningkatan $\mathrm{SpO}^{2}$ karena dalam penelitian ini usia responden keseluruhan lebih dari 45 tahun. Proses ekspirasi secara normal merupakan proses mengeluarkan nafas tanpa menggunakan energy. PLB juga akan menyebabkan obstruksi jalan nafas dihilangkan sehingga resistensi pernafasan menurun. Penurunan resistensi pernafasan akan memperlancar udara yang dihembuskan dan atau dihirup. Sedangkan 7 responden mengalami peningkatan $\mathrm{SpO}^{2}$ namun berada pada rentang hipoksia ringan, dan 4 responden mengalami peningkatan namun tidak signifikan, dan masih berada pada hipoksia sedang, hal ini disebabkan

Usastiawaty Cik Ayu Saadiah lsnainy' Program Studi Diploma III Keperawatan Universitas Malahayati.

Email: usastiawatycasi@gmail.com

Sekardhyta Ayuning Tias ${ }^{2^{*}}$ RSUD Dr. H. Abdul Moeloek Bandar Lampung. *Email: sekara459@gmail.com 
Pengaruh posisi condong kedepan dan terapi pursed lips breathing terhadap derajat sesak napas penderita Penyakit Paru Obstruktif Kronik (PPOK)

karena faktor penyakit yang diderita oleh responden, dan lama waktu menderita sakit.

Bernafas PLB selain ekspirasi dipaksa juga diperpanjang. Upaya memperpanjang ekspirasi akan mencegah udara dihembuskan secara spontan yang dapat berakibat paru kolap atau runtuh, dengan demikian dengan bernafas PLB membantu mengeluarkan udara yang terperangkap pada pasien PPOK sehingga CO2 di paru dapat dikeluarkan.

\section{SIMPULAN}

Rata-rata kondisi pernafasan pasien PPOK sebelum diberikan terapi CKD Dan PLB terhadap 17 responden, dengan mean $\mathrm{SpO}^{2}$ pada responden sebesar 86,71 standar deviasi 1,649 standar eror 0,400. Rata-rata kondisi pernafasan pasien PPOK sesudah diberikan terapi CKD Dan $\mathrm{PLB}$ terhadap 17 responden, dengan mean $\mathrm{SpO}^{2}$ pada responden sebesar 92,82 standar deviasi 2,856 standar eror 0,693. Hasil uji statistik menggunakan tes-dependent didapat nilai $p$-value 0.000 artinya terdapat Pengaruh Posisi CKD Dan PLB Terhadap Tingkat Sesak Nafas dengan peningkatan rata-rata $\mathrm{SpO}^{2} 90$ menjadi 97 setelah diberi intervensi.

\section{SARAN}

Diharapkan dapat dijadikan masukan dalam membuat standar operasional penatalaksanaan pasien dengan PPOK sebagai upaya untuk meningkatkan kualitas asuhan keperawatan dengan cara memberikan posisi CKD dan PLB. Perawat dapat memberikan asuhan keperawatan komplementer untuk mengurangi resiko sesak nafas tanpa menggunakan obat.

\section{DAFTAR PUSTAKA}

Alsaggaf, M., Seeni, R., Delaney, M., Williams, J., \& Gutierrez, G. (2017). Probability Of Emphysema In Patients With No Obstruction And Reduced Dlco. In C22. COPD Phenotypes (pp. A4996-A4996). American Thoracic Society.
Anwar, D., Chan, Y., \& Basyar, M. (2012). Hubungan derajat sesak napas penderita penyakit paru obstruktif kronik menurut kuesioner modified medical research council scale dengan derajat penyakit paru obstruktif kronik. J Respir Indo. 2012; 32: 200, 7.

Ariyani, D. R., Sarbini, D., \& Yuliati, R. (2013). Hubungan antara status gizi dan pola makan dengan fungsi paru pada pasien penyakit paru obstruktif 2. Kronik (PPOK) di balai besar kesehatan paru masyarakat Surakarta.

Bakti, A. K., \& Dwi, R. K. (2015). Pengaruh Pursed Lip Breathing Exercise Terhadap Penurunan Tingkat Sesak Napas Pada Penyakit Paru Obstruksi Kronik (Ppok) Di Balai Besar Kesehatan Paru Masyarakat BBKPM Surakarta (Doctoral dissertation, Universitas Muhammadiyah Surakarta).

Black, J. M., \& Hawks, J. H. (2014). Keperawatan medikal bedah: manajemen klinis untuk hasil yang diharapkan. Elsevier (Singapore).

Edwin, H. M., Basuki, N., Physio, M., \& Isnaini, H. S. (2013). Pengaruh Pursed-Lip Breathing Terhadap Penurunan Respiratory Rate (Rr) Dan Peningkatan Pulse Oxygen Saturation (Spo2) Pada Penderita Ppok (Doctoral dissertation, Universitas Muhammadiyah Surakarta).

Huriah, T., \& Ningtias, D. W. (2017). Pengaruh Active Cycle Of Breathing Technique Terhadap Peningkatan Nilai VEP1, Jumlah Sputum, dan Mobilisasi Sangkar Thoraks Pasien PPOK. IJNP (Indonesian Journal of Nursing Practices), 1(2), 44-54.

Khasanah, S., \& Maryoto, M. (2016). Pengaruh posisi condong ke depan (CKD) dengan pursed lips breathing (PLB) terhadap peningkatan kondisi pernafasan pasien Penyakit Paru Obstruktif Kronik (PPOK). 
Pengaruh posisi condong kedepan dan terapi pursed lips breathing terhadap derajat sesak napas penderita Penyakit Paru Obstruktif Kronik (PPOK)

Khotimah, S. (2013). Latihan Endurance Meningkatkan Kualitas Hidup Lebih Baik Dari Pada Latihan Pernafasan Pada Pasien PPOK Di BP4 Yogyakarta. Sport and Fitness Journal, 1(1), 20-32.

Kurniawati, S. (2012). Pengaruh Chest Therapy Terhadap Penurunan Sesak Nafas Dengan Parameter Respiratory Rate Pada Anak Bronchitis (Doctoral dissertation, Universitas Muhammadiyah Surakarta).

Laksana, M. A., \& Berawi, K. (2015). Faktor-Faktor Yang Berpengaruh pada Timbulnya Kejadian Sesak Napas Penderita Asma Bronkial. Jurnal Majority, 4(9), 64-68.

Perhimpunan Dokter Paru Indonesia. (2011). Penyakit paru obstruktif kronik. Diagnosis dan Penatalaksanaan. Jakarta: Perhimpunan Dokter Paru Indonesia, 1-88.

Permadi, A. W., \& Wahyudi, A. T. (2017). Pengaruh pursed lip breathing dan sustained maximal inspiration terhadap peningkatkan kekuatan otot pernapasan untuk mengurangi keluhan sesak napas pada kasus kardio respirasi. Interest: Jurnal IImu Kesehatan, 6(2).

Purwanti, A. M. D., Hartoyo, M., \& Wulandari, M. (2016). Efektifitas tehnik relaksasi nafas dalam dan posisi tripod terhadap laju pernafasan pasien PPOK di RS $H$. Soewondo Kendal. Karya IImiah.
Seraswati, N. N. (2017). Pengaruh Incentive Spirometry Dan Pursed Lip Breathing Terhadap Kapasitas Inspirasi, Gejala Sesak Napas, Kapasitas Exercise, Dan Kualitas Hidup Penderita Penyakit Paru Obstruktif Kronik Stabil (Doctoral Dissertation, Universitas Sebelas Maret).

Simanjuntak, R. H., Engka, J. N., \& Marunduh, S. R. (2016). Pengaruh latihan fisik akut terhadap saturasi oksigen pada pemain basket mahasiswa Fakultas Kedokteran Unsrat. Jurnal e-Biomedik, 4(1).

Singh, D., Agusti, A., Anzueto, A., Barnes, P. J., Bourbeau, J., Celli, B. R., \& Varela, M. V. L. (2019). Global strategy for the diagnosis, management, and prevention of chronic obstructive lung disease: the GOLD science committee report 2019. European Respiratory Journal, 53(5), 1900164

Sudoyo, A. W., Setiyohadi, B., Alwi, I., Simadibrata, M., \& Setiati, S. (2009). Buku Ajar IImu Penyakit Dalam Jilid II edisi V. Jakarta: Interna Publishing, 310, 1973-1982.

Takatelide, F. W., Kumaat, L. T., \& Malara, R. T. (2017). Pengaruh Terapi Oksigenasi Nasal Prong Terhadap Perubahan Saturasi Oksigen Pasien Cedera Kepala Di Instalasi Gawat Darurat Rsup Prof. Dr. RD Kandou Manado. Jurnal Keperawatan, 5(1).

Tanto, C., Liwang, F., Hanifati, S., \& Pradipta, E. A. (2014). Kapita selekta kedokteran. Jakarta: Media Aesculapius, 329-30. 